\title{
Characterisation of thiocyanate degradation in a mixed culture activated sludge process treating coke wastewater
}

\author{
Eleanor Raper ${ }^{\text {a }}$, Tom Stephenson ${ }^{\text {a }}$, Raymond Fisher ${ }^{\text {b }}$, David, R. Anderson ${ }^{\text {b }}$, Ana Soares ${ }^{\mathrm{a}^{*}}$. \\ ${ }^{a}$ Cranfield Water Sciences Institute, Cranfield University, Cranfield, MK43 OAL, UK. \\ ${ }^{b}$ Tata Steel, Group Health Safety and Environment, Swinden Technology Centre, Rotherham, S60 3AR,
} $U K$.

\begin{abstract}
Microbial degradation of thiocyanate $\left(\mathrm{SCN}^{-}\right)$has been reported to suffer from instability highlighting the need for improved understanding of underlying mechanisms and boundaries. Respirometry, batch tests and DNA sequencing analysis were used to improve understanding of a mixed culture treating coke wastewater rich in $\mathrm{SCN}^{-}$. An uncultured species of Thiobacillus was the most abundant species (26\%) and displayed similar metabolic capabilities to Thiobacillus denitrificans and Thiobacillus thioparus. Thiocyanate was hydrolysed /oxidised to $\mathrm{NH}_{4}{ }^{+}-\mathrm{N}, \mathrm{HCO}_{3}{ }^{-}$and $\mathrm{SO}_{4}{ }^{2-}$. Nevertheless, at 360-2100 $\mathrm{mg} \mathrm{SCN}^{-} / \mathrm{L}$ a breakdown in the degradation pathway was observed.

Respirometry tests demonstrated that $\mathrm{NH}_{4}{ }^{+}-\mathrm{N}$ was inhibitory to $\mathrm{SCN}^{-}$degradation $\left(\mathrm{IC}_{50}\right.$ : $316 \mathrm{mg} / \mathrm{L})$. Likewise, phenol (180 mg/L) and hydroxylamine $(0.25-16 \mathrm{mg} / \mathrm{L})$ reduced $\mathrm{SCN}^{-}$degradation by $41 \%$ and ca. $7 \%$, respectively. The understanding of the $\mathrm{SCN}^{-}$ degradation pathways can enable stable treatment efficiencies and compliance with effluent of $<4 \mathrm{mg} \mathrm{SCN} / \mathrm{L}$, required by the Industrial Emissions Directive.
\end{abstract}


Keywords: Thiocyanate; Coke wastewater; Thiobacillus denitrificans; Thiobacillus thioparus.

\section{Introduction}

Production of coke for steel making, generates wastewater which contains significant quantities of thiocyanate $\left(\mathrm{SCN}^{-}\right)$ranging from 50 to $400 \mathrm{mg} / \mathrm{L}$ (Pan et al., 2018a; 2018b; Raper et al., 2019; Staib and Lant, 2007; Vázquez et al., 2006). Thiocyanate is generated when cyanide and sulphur react under the high temperatures associated with the coke making process (Kim and Katayama, 2000). Emissions of $\mathrm{SCN}^{-}$are regulated in coke making wastewater by the Industrial Emissions Directive (IED) and must be reduced to less than $4 \mathrm{mg} / \mathrm{L}$ (European Commission, 2013). Removal of $\mathrm{SCN}^{-}$from the coke wastewater can be achieved through treatment in an activated sludge process (ASP), where biological flocs are mixed with the raw wastewater enabling degradation of target compounds in the wastewater. The treatment of $\mathrm{SCN}^{-}$in an ASP however, is known to be sensitive and unstable, which can lead to treatment losses (Staib and Lant, 2007; Vázquez et al., 2006). Staib and Lant (2007) reported $\mathrm{SCN}^{-}$degradation to be the most sensitive process after nitrification.

Due to its production in many industrial processes there has been an appreciable interest in $\mathrm{SCN}^{-}$degradation (Combarros et al., 2015; Grigor et al., 2009, 2006; Hung and Pavlostathis, 1999; Watts and Moreau, 2016). Thiocyanate degrading bacteria have been isolated and identified from a variety of sources including the genera Arthrobacter, Bacillus, Escherichia, Pseudomonas, Thiobacillus, Acinetobacter, Burkholderia, Chryseobacterium, Klebsiella, Ralstonia and Methylobacterium (Boucabeille et al., 1994; Chaudhari and Kodam, 2010; Huang et al., 2013; Hung and Pavlostathis, 1997; 
Kelly and Wood, 2000a; Kim and Katayama, 2000; Lee et al., 2008, 2003; Pan et al., 2018a; Sorokin et al., 2001). Numerous pathways have been identified for the biodegradation of $\mathrm{SCN}^{-}$, including through the action of autotrophic and heterotrophic bacteria (Table 1). Autotrophic bacteria utilise inorganic carbon from $\mathrm{SCN}^{-}$as a carbon source whilst heterotrophic $\mathrm{SCN}^{-}$degraders utilise $\mathrm{SCN}^{-}$as a source of nitrogen and use organic carbon as an energy source (Watts and Moreau, 2016). Autotrophic pathways are the most commonly reported, whereas heterotrophic pathways are less commonly reported and have mainly been linked with tests in synthetic wastewaters (Table 1) (Watts and Moreau, 2016). Several end products have been reported including ammonia $\left(\mathrm{NH}_{4}{ }^{+} \mathrm{N}\right)$, sulphate $\left(\mathrm{SO}_{4}{ }^{2-}\right)$, carbonyl sulphide $(\mathrm{COS})$ and trithionate. Ammonia and $\mathrm{SO}_{4}{ }^{2-}$ have both been reported to be produced under both aerobic and anoxic conditions. Carbonyl sulphide has only been reported to occur under aerobic conditions whilst trithionate has only been reported to arise under anoxic conditions whilst COS has only been observed to arise under aerobic conditions.

Additionally, a number of intermediate compounds have been reported including thiosulphate $\left(\mathrm{S}_{2} \mathrm{O}_{3}{ }^{2-}\right)$, tetrathionate $\left(\mathrm{S}_{4} \mathrm{O}_{6}{ }^{2-}\right)$ and cyanate $\left(\mathrm{OCN}^{-}\right)$. As there are several possible degradation pathways, a greater understanding of the degradation pathway and bacterial requirements will provide a better understanding of the requirements which need to be met to maintain stable operation in wastewater treatment plants.

Treatment of $\mathrm{SCN}^{-}$in coke wastewater is further complicated by the presence of numerous species that are associated with toxicity. Coke wastewater contains $\mathrm{NH}_{4}{ }^{+}-\mathrm{N}$, phenol, polycyclic aromatic hydrocarbons (PAHs) and trace metals (Bai et al., 2010; Marañón et al., 2008; Raper et al., 2017; Vázquez et al., 2006). Concentrations of such pollutants can vary significantly between and within different treatment works in 
response to the changing coal blends and operational conditions (Marañón et al., 2008). Ammonia concentrations have been reported to vary between 50 and $500 \mathrm{mg} / \mathrm{L}$ with similar fluctuations observed for phenol concentrations $(60-400 \mathrm{mg} / \mathrm{L})$ (Bai et al., 2010; Marañón et al., 2008; Vázquez et al., 2006). The sum of 6 PAHs (sum of fluoranthene, benzo[b]fluoranthene, benzo[k]fluoranthene], benzo[a]pyrene, indeno[1,2,3-cd]pyrene and benzo[g,h,i]perylene) was reported at $179 \pm 35 \mu \mathrm{g} / \mathrm{L}^{-1}$ whilst total trace metals (sum of $\mathrm{Al}, \mathrm{Cr}, \mathrm{Mn}, \mathrm{Fe}, \mathrm{Co}, \mathrm{Ni}, \mathrm{Cu}, \mathrm{Zn}, \mathrm{As}, \mathrm{Cd}$ and $\mathrm{Pb}$ ) were reported at $4216 \mu \mathrm{g} / \mathrm{L}$ (Raper et al., 2017).

Paruchuri, Shivaraman and Kumaran (1990) reported that a mixed culture containing Pseudomonas and Bacillus species was capable of degrading up to $1,400 \mathrm{mg} / \mathrm{L}$ of SCN ${ }^{-}$ in batch culture over 6 days. Furthermore, they investigated the impact of phenol and $\mathrm{NH}_{4}{ }^{+}-\mathrm{N}$, demonstrating that the latter had no inhibitory effect up to $2000 \mathrm{mg} / \mathrm{L}$, after which prolonged oxidation was required to maintain $\mathrm{SCN}^{-}$degradation. Thiocyanate degradation was more sensitive to phenol, with $50 \mathrm{mg} / \mathrm{L}$ of phenol prolonging the oxidation time and $500 \mathrm{mg} / \mathrm{L}$ resulting in complete inhibition. In contrast, Staib and Lant (2007) suggested that under continuous treatment conditions phenol would exert no inhibitory influence as its degradation rate would exceed that of $\mathrm{SCN}^{-}$. Jeong and Chung (2006) investigated the degradation of $\mathrm{SCN}^{-}$in a laboratory-scale continuous process. Coke oven wastewater was diluted to create a wastewater characterised by $\mathrm{SCN}^{-}$levels of $3000-7000 \mathrm{mg} / \mathrm{L}$. The diluted wastewater was then passed through a fluidized biofilm reactor with a $40 \%$ filling ratio. When the volumetric loading rate of thiocyanate exceeded ca. $4 \mathrm{~kg} / \mathrm{m}^{3} . \mathrm{d}$ the biodegradation rate slowly declined demonstrating a substrate inhibition effect. Outlet $\mathrm{SCN}^{-}$concentrations $>50 \mathrm{mg} / \mathrm{L}$ were correlated with declining degradation rates. 
Observations into $\mathrm{SCN}^{-}$degradation to date have been controversial with further investigation being required. The objective of this study was to characterise the mixed culture responsible for $\mathrm{SCN}^{-}$degradation in the ASP treating coke wastewater to enable a greater understanding of the conditions required to maintain stable treatment efficiencies and enable compliance with the IED emission limit of $<4 \mathrm{mg} / \mathrm{L}$. An uncultured species of Thiobacillus was identified which had similar metabolic characteristics to T. thioparus and T. denitrificans. Degradation of SCN- produced ammonia $\mathrm{NH}_{4}{ }^{+}-\mathrm{N}, \mathrm{HCO}_{3}{ }^{-}$and $\mathrm{SO}_{4}{ }^{2-}$. Ammonia, phenol and hydroxylamine demonstrated inhibitory effects. The stable degradation of $\mathrm{SCN}^{-}$required mesophilic temperatures.

\section{Materials and Methods}

\subsection{Wastewater and activated sludge biomass}

Coke wastewater and activated sludge biomass were collected from a full-scale ASP at a UK integrated steelworks. The ASP consisted of aeration tanks (combined volume of $2,280 \mathrm{~m}^{3}$ ) receiving coke wastewater at an average flow rate of $680 \mathrm{~m}^{3} / \mathrm{d}$ giving an average hydraulic retention time (HRT) of 21 hours. Activated sludge biomass was taken from the return activated sludge (RAS) line and was characterised by an average sludge retention time (SRT) of ca. 38 days. The MLSS of the RAS varied in response to sludge wasting and therefore varied between 16,000 and $33,000 \mathrm{mg} / \mathrm{L}$.

The coke wastewater was characterised by a sCOD of $644 \pm 130 \mathrm{mg} / \mathrm{L}$. Thiocyanate and phenol concentrations were $95 \pm 18 \mathrm{mg} / \mathrm{L}$ and $20 \pm 2 \mathrm{mg} / \mathrm{L}$ respectively. Ammonia contributed the highest concentration of nitrogen to the wastewater at an average of $91 \pm 24 \mathrm{mg} / \mathrm{L}$ as $\mathrm{NH}_{4}{ }^{+}-\mathrm{N}$ with small contributions from $\mathrm{NO}_{3}{ }^{-}-\mathrm{N}(3 \pm 2.5 \mathrm{mg} / \mathrm{L})$ and $\mathrm{NO}_{2}{ }^{-}-$ 
$\mathrm{N}(3 \pm 2.9)$. The wastewater exhibited a $\mathrm{pH}$ of $7.8 \pm 0.3$. Concentrations of pollutants therefore fell within the typical range for coke wastewater previously reported for this site as well as those reported in the wider literature (Marañón et al., 2008; Raper et al., 2019; Staib and Lant, 2007; Vázquez et al., 2006).

\subsection{Impact of temperature on $\mathrm{SCN}^{-}$degradation}

Batch tests were conducted to investigate the impact of temperature and concomitant nitrification and $\mathrm{SCN}^{-}$degradation. Batch tests with a $0.95 \mathrm{~L}$ working volume were completed using coke wastewater and activated sludge biomass to produce a mixed liquor suspended solids concentration (MLSS) of $4500 \mathrm{mg} / \mathrm{L}$. Air pumps enabled dissolved oxygen to be maintained at ca. $3 \mathrm{mg} / \mathrm{L}$. Samples were taken systematically to demonstrate the influence of temperature and concomitant nitrification. Temperature was maintained through a water bath at $25^{\circ} \mathrm{C}$ to reflect the target conditions on the fullscale ASP, however, to investigate the impact of temperature some batch tests were left without heat provision. These batch tests were therefore subject to diurnal temperature variations ranging from 8 to $21^{\circ} \mathrm{C}$.

\subsection{Respirometry}

Activated sludge biomass was collected in advance of each run of the respirometer and was stored at $2-5^{\circ} \mathrm{C}$ for a maximum of 48 hours. The respirometer (Environmental Services, UK) consisted of ten respirometric cells (450 $\mathrm{ml}$ working volume) positioned in a water bath maintained at a temperature of $25 \pm 1^{\circ} \mathrm{C}$ to reflect the target operational conditions of the full-scale ASP. Temperature was controlled by a Grant thermostatic circulator (GD120), UK. Oxygen supply to the respirometric cells was enabled via the provision of a copper sulphate pentahydrate solution $(25 \% \mathrm{w} / \mathrm{v})$. Carbon dioxide was 
removed by a $2 \mathrm{M}$ sodium hydroxide solution. Oxygen consumption data were recorded by a data logger at 20 minute intervals. Oxygen concentration within each respirometric cell was maintained via agitation using a magnetic stirrer. Activated sludge biomass and coke making wastewaters were combined to replicate the mixed liquor concentrations in the full-scale treatment process of $8300 \mathrm{mg} / \mathrm{L}$.

In order to investigate the inhibition of $\mathrm{SCN}^{-}$the mixed liquor from the coke making process was spiked with solutions of hydroxylamine hydrochloride $\left(\mathrm{NH}_{2} \mathrm{OH}\right)$, potassium nitrite and potassium nitrate at concentrations varying from $0.25-16 \mathrm{mg} / \mathrm{L}$. The impact of $\mathrm{SCN}^{-}$was investigated through spiking potassium thiocyanate at concentrations from $250-2000 \mathrm{mg} / \mathrm{L}$. The impact of ammonia and sulphate were investigated by spiking ammonium chloride and potassium sulphate at concentrations of $250-1500 \mathrm{mg} / \mathrm{L} \mathrm{NH}_{4}{ }^{+}-\mathrm{N}$ and $1000-2000 \mathrm{mg} / \mathrm{L} \mathrm{SO}_{4}{ }^{2-}$ respectively. Inhibition tests were completed over 4-5 days and repeated in triplicate with decreased oxygen consumption in the test cells in comparison to the control cells representing inhibition of the biomass.

For each compound and concentration, the percentage inhibition was calculated takin in consideration the variation in oxygen consumption. The logarithm of the concentration of each compound was calculated and plotted against the observed inhibition. The half maximal inhibitory concentration (IC50) was then plotted and the inverse logarithm of the compound concentration calculated to provide the IC50."

\subsection{Chemical analysis}

Samples were filtered (0.45 $\mu \mathrm{m}$ syringe filters -VWR) and $\mathrm{pH}$ recorded (Jenway 3540, UK). Mixed liquor suspended solids were analysed according to standard methods 
(Eaton, 2005). Merck cell test kits were used to determine the concentrations of $\mathrm{NO}_{2}{ }^{-} \mathrm{N}$, $\mathrm{NO}_{3}{ }^{-}-\mathrm{N}, \mathrm{NH}_{4}{ }^{+}-\mathrm{N}, \mathrm{SO}_{4}{ }^{2-}$ and soluble chemical oxygen demand (sCOD) following the manufacturer's instructions. Thiocyanate and phenol were determined colorimetrically at a wavelength of 465 and $510 \mathrm{~nm}$, respectively, using a Jenway 6300 spectrophotometer (Staffordshire, UK). Thiocyanate was determined by a method based upon the reaction of thiocyanate with iron (III) to produce an orange-red colour based on a red complex (The Institution of Gas Engineers, 1971) while phenol was determined using 4-aminoantipyrene based upon ISO 6439:1990 (ISO, 1990).

\subsection{Molecular microbial ecology}

Activated sludge biomass was taken from four respirometric cells which were operated under controlled conditions. Activated sludge biomass was analysed through polymerase chain reaction (PCR) in order to quantify the microbial diversity in the ASP mixed liquor. The biomass was placed into a lysing matrix tube and the deoxyribonucleic acid (DNA) extracted (MPBIO FastDNA Spin Kit for soil, Santa Ana, USA). The V4 and V5 regions of the 16S ribosomal RNA (rRNA) gene were targeted with the universal primers 515F and 926R (Quince et al., 2011). Error correcting golay barcodes enabled sample multiplexing (Hamady et al., 2012). Polymerase chain reaction products were purified using HighPrep magnetic beads (Magbio, Gaithersburg USA) and QuantiFluor ONE (Promega, Madison USA). An equimolar pool of amplicons was sequenced using Illumina MiSeq with 2x300 v2 chemistry (Illumina, San Diego USA). Quantitative Insights Into Microbial Ecology (QIIME) 1.9 (Caporaso et al., 2010) and the SILVA 16S rRNA gene database v123.1 (Quast et al., 2013) were used for sequence analysis. The $16 \mathrm{~S}$ rRNA gene sequences were grouped at $97 \%$ similarity to create operational taxonomic units (OTUs). Representative sequences from each 
OTU were then taxonomically assigned using the SILVA database. If the $16 \mathrm{~S}$ sequences were not found in the database, these were described as "uncultured", "ambiguous" or "other". An uncultured sequence was one in which the sequence matched a database sequence but taxonomy was unavailable. An ambiguous species referred to a sequence which had more than a $97 \%$ similarity to more than one sequence of the genus. A sequence was referred to as "other" when the sequence could be identified no further than the genus level.

\section{Results and Discussion}

\subsection{Thiocyanate degradation in the mixed culture}

Respirometry tests showed that the mixed culture was capable of $\mathrm{SCN}^{-}$removal at a range of initial $\mathrm{SCN}^{-}$concentrations (Table 2). After 120 hours, removal of $110 \mathrm{mg} / \mathrm{L}$ $\mathrm{SCN}^{-}$was complete. For initial $\mathrm{SCN}^{-}$concentrations of 360 to $610 \mathrm{mg} / \mathrm{L}$, the average $\mathrm{SCN}^{-}$removal was 19 and $13 \%$, respectively. Hence, as the initial $\mathrm{SCN}^{-}$concentrations increased, removal efficiencies declined. Whether the observed decline in removal efficiency was as a result of toxicity or the requirement for longer degradation times deserves further investigation. Despite this, at an almost 20 times increase in the initial $\mathrm{SCN}^{-}$concentration to $2109 \mathrm{mg} / \mathrm{L}, 58 \%$ of the initial $\mathrm{SCN}^{-}$was degraded after 5 days demonstrating the ability of the mixed culture to cope with high $\mathrm{SCN}^{-}$concentrations. The mixed culture therefore had a high $\mathrm{SCN}^{-}$removal capacity similar to the mixed consortium investigated by Paruchuri, Shivaraman and Kumaran (1990). Similarly, a co-culture of $\mathrm{SCN}^{-}$degrading bacteria Klebsiella pneumoniae and Ralstonia showed decreased removal efficiencies at increased initial concentrations in batch tests conducted by Chaudhari and Kodam (2010). Degradation efficiencies declined from 
$100 \%$ at $500 \mathrm{mg} / \mathrm{L} \mathrm{SCN}^{-}$to $76 \%, 57 \%, 42 \%$, and $34 \%$ at $1000,1,500,2,000$, and 2,500 $\mathrm{mg} / \mathrm{L} \mathrm{SCN}^{-}$respectively.

On the other hand, different $\mathrm{SCN}^{-}$initial concentrations resulted in different end products (Table 2). When the initial $\mathrm{SCN}^{-}$concentration was $110 \mathrm{mg} / \mathrm{L}$ (control conditions), the ammonia was observed to increase from $70 \mathrm{mg} / \mathrm{L}$ to $110 \mathrm{mg} / \mathrm{L}$. Ammonia is produced during the degradation of $\mathrm{SCN}^{-}$through all reported degradation pathways (Table 1). For each mole of $\mathrm{SCN}^{-}$degraded Kim et al. (2008) reported the production of 0.24 moles $\mathrm{NH}_{4}{ }^{+}-\mathrm{N}$. The mixed culture in the present investigation produced 0.26 moles of $\mathrm{NH}_{4}{ }^{+}-\mathrm{N}$ from each mole of $\mathrm{SCN}^{-}$degraded. Under control conditions, the production of $\mathrm{NH}_{4}{ }^{+}-\mathrm{N}$ was in line with the theoretical $\mathrm{NH}_{4}{ }^{+}-\mathrm{N}$ production expected $(28 \mathrm{mg} / \mathrm{L})$. As the initial $\mathrm{SCN}^{-}$concentration increased, however, there was a decline in $\mathrm{NH}_{4}{ }^{+}-\mathrm{N}$ production suggesting a breakdown in the degradation process. Hung and Pavlostathis (1997) reported that $\mathrm{SCN}^{-}$degradation proceeds in a series of steps (Table 1). Firstly $\mathrm{SCN}^{-}$is hydrolysed forming $\mathrm{OCN}^{-}$which is subsequently hydrolysed to form $\mathrm{NH}_{4}{ }^{+}-\mathrm{N}$ and bicarbonate $\left(\mathrm{HCO}_{3}{ }^{-}\right)$whilst sulphur is oxidised to produce $\mathrm{SO}_{4}{ }^{2-}$. Lower than expected concentrations of $\mathrm{NH}_{4}{ }^{+}-\mathrm{N}$ suggests that $\mathrm{SCN}^{-}$hydrolysis occurred but $\mathrm{OCN}^{-}$hydrolysis did not.

Cyanate is hydrolysed by the enzyme cyanase producing $\mathrm{CO}_{2}$ and $\mathrm{NH}_{4}{ }^{+}-\mathrm{N}$ (Douglas Gould et al., 2012; Kozliak et al., 1995). The E.coli enzyme is the only cyanase which has been studied in detail (Walsh et al., 2000). Bicarbonate is believed to be involved in a nucleophilic attack on $\mathrm{OCN}^{-}$which produces $\mathrm{CO}_{2}$ and carbamate (Walsh et al., 2000). Decarboxylation then takes place producing $\mathrm{CO}_{2}$ and $\mathrm{NH}_{4}{ }^{+}-\mathrm{N}$ (Walsh et al., 2000). Although cyanase is induced by $\mathrm{OCN}^{-}$, high cyanate concentrations can equally have a toxic effect (Hung and Pavlostathis, 1997). Both $\mathrm{HCO}_{3}{ }^{-}$and $\mathrm{OCN}^{-}$are capable of 
binding at the other substrate binding site resulting in a dead-end complex (Anderson and Little, 1986). It is therefore suspected that at higher concentrations of $\mathrm{SCN}^{-}$the hydrolysis of $\mathrm{SCN}^{-}$proceeded more rapidly producing high concentrations of $\mathrm{OCN}^{-}$ which in turn led to inhibition of cyanase. As a result of the lower cyanase activity $\mathrm{OCN}^{-}$would accumulate further and no $\mathrm{NH}_{4}{ }^{+}-\mathrm{N}$ would be produced (Hung and Pavlostathis, 1997).

The degradation of $\mathrm{SCN}^{-}$during the treatment of coke wastewater has typically been reported to occur in aerobic conditions. Kim et al. $(2011,2008)$ reported that $\mathrm{SCN}^{-}$ degradation took place in the aerobic tank of the laboratory-scale anoxic-aerobic ASP. In contrast, however, previous work on the current activated sludge biomass revealed that the biomass was capable of completely removing $\mathrm{SCN}^{-}$in both aerobic conditions and anoxic conditions (Raper et al., 2019, 2017). This $\mathrm{SCN}^{-}$degradation in the anoxic cell of a pilot-scale anoxic-aerobic ASP was possible with biomass taken from an aerobic process without any acclimatisation period.

Table 2: Impact of initial $\mathrm{SCN}^{-}$concentration on $\mathrm{SCN}^{-}$removal and end product formation in the mixed culture after 5 days in the respirometer.

\subsection{Impact of nitrogen compounds on $\mathrm{SCN}^{-}$degradation}

Nitrification is an essential process in the removal of nitrogen from coke wastewater. The degradation of $\mathrm{SCN}^{-}$and nitrification both occur in the ASP under aerobic conditions. Therefore, compounds associated with the nitrogen cycle were assessed for their impact on $\mathrm{SCN}^{-}$degradation. Nitrate, nitrite and hydroxylamine $\left(\mathrm{NH}_{2} \mathrm{OH}\right)$ were 
spiked into the mixed culture and the impact on SCN- degradation monitored through respirometry. After 4 days neither nitrite nor nitrate had any impact on $\mathrm{SCN}^{-}$ degradation efficiency at concentrations ranging from $0.25 \mathrm{mg} / \mathrm{L}$ to $16 \mathrm{mg} / \mathrm{L}$. Hydroxylamine, an intermediate compound produced during nitrification(Gerardi, 2002)(Gerardi, 2002)(Gerardi, 2002)(Gerardi, 2002)(Gerardi, 2002)(Gerardi, 2002)(Gerardi, 2002)(Gerardi, 2002)(Gerardi, 2002)(Gerardi, 2002), can be found at low concentrations in nitrifying activated sludge processes (Gerardi, 2002) and as such was also investigated. Hydroxylamine resulted in a small inhibitory response leading to a 4 to $7 \%$ reduction in $\mathrm{SCN}^{-}$degradation at concentrations of $0.25 \mathrm{mg} / \mathrm{L}$ to $16 \mathrm{mg} / \mathrm{L}$. Inhibition did not increase with increased $\mathrm{NH}_{2} \mathrm{OH}$ concentrations. Whilst $\mathrm{NH}_{2} \mathrm{OH}$ may result in a low level of inhibition, $\mathrm{SCN}^{-}$degradation proceeds faster than nitrification. This can be observed in Figure 1 which demonstrates an accumulation of ammonia (negative nitrification efficiency) after 24 hours due to degradation of $\mathrm{SCN}^{-}$which produces additional ammonia to that already in the coke wastewater. $\mathrm{SCN}^{-}$removal was complete at 72 hours whilst nitrification was $<40 \%$, taking 5 days to reach $90 \%$. Any inhibitory impact of $\mathrm{NH}_{2} \mathrm{OH}$ would therefore be minimal.

\subsection{Impact of ammonia, sulphate and phenol on $\mathrm{SCN}^{-}$degradation}

The impact of phenol, $\mathrm{NH}_{4}{ }^{+}-\mathrm{N}$ and $\mathrm{SO}_{4}{ }^{2-}$ on $\mathrm{SCN}^{-}$degradation was also investigated as each of the compounds may be found at elevated concentrations in the mixed liquor due to their presence in the raw liquor or due to their production during $\mathrm{SCN}^{-}$degradation. The average $\mathrm{NH}_{4}{ }^{+}-\mathrm{N}$ concentration at 0 hours in the respirometer was $82 \mathrm{mg} / \mathrm{L}$ (106 
$\left.\mathrm{mg} / \mathrm{L} \mathrm{NH}_{4}{ }^{+}-\mathrm{N}\right)$. An additional $250-1500 \mathrm{mg} / \mathrm{L} \mathrm{NH}_{4}{ }^{+}-\mathrm{N}$ was subsequently spiked to the coke wastewater to assess the impact of $\mathrm{NH}_{4}{ }^{+}-\mathrm{N}$ on $\mathrm{SCN}^{-}$degradation.

Ammonia was observed to have an inhibitory influence on $\mathrm{SCN}^{-}$degradation.

Thiocyanate removal efficiencies declined by 24,19 and $22 \%$ upon the addition of 250 , 500 and $1000 \mathrm{mg} / \mathrm{L} \mathrm{NH}_{4}{ }^{+}-\mathrm{N}$. At $1500 \mathrm{mg} / \mathrm{L} \mathrm{NH}_{4}{ }^{+}-\mathrm{N}$ the degradation of $\mathrm{SCN}^{-}$declined by $43 \%$. Oxygen consumption in the respirometer tests was observed to decline (Figure 2) which was likely to be associated with $\mathrm{NH}_{4}{ }^{+}-\mathrm{N}$ toxicity. The calculated half maximal inhibitory concentration $\left(\mathrm{IC}_{50}\right)$ for $\mathrm{NH}_{4}{ }^{+}-\mathrm{N}$ was $316 \mathrm{mg} / \mathrm{L} \mathrm{NH}_{4}{ }^{+}-\mathrm{N}$. The mixed culture was therefore more sensitive to $\mathrm{NH}_{4}{ }^{+}-\mathrm{N}$ concentrations than the mixed culture described by Paruchuri, Shivaraman and Kumaran (1990). Ammonia loading to the ASP is therefore a critical parameter that should be controlled in the operation of ASPs treating coke wastewater.

Sulphate at concentrations between $80-2000 \mathrm{mg} / \mathrm{L}$, had little impact on $\mathrm{SCN}^{-}$ degradation suggesting that no inhibition occurred as a result of its formation during the degradation process. The impact of varying phenol concentration on the $\mathrm{SCN}^{-}$removal was investigated due to concerns around its toxicity. The results obtained indicated that phenol had an inhibitory role on $\mathrm{SCN}^{-}$degradation with the addition of 80,130 and 180 $\mathrm{mg} / \mathrm{L}$ phenol resulting in a 29, 38 and $41 \%$ decrease in $\mathrm{SCN}^{-}$removal respectively. Increased phenol results in higher organic carbon availability which can increase the growth of heterotrophic bacteria in turn increasing competition for dissolved oxygen with the slower-growing autotrophic bacteria (Kim et al. 2013a).

\subsection{Temperature}


The mixed culture was sensitive to process temperature (Figure 3). When the temperature was maintained at mesophilic conditions $\left(25 \pm 1{ }^{\circ} \mathrm{C}\right) \mathrm{SCN}^{-}$degradation was complete within 24 hours. When temperature was not controlled, it fluctuated between 8 $-21^{\circ} \mathrm{C}$ (psychrophilic range of temperatures) and the $\mathrm{SCN}^{-}$degradation was strongly affected decreasing to $2-26 \%$. The optimal temperature for the mixed culture was therefore within the mesophilic range of temperatures, fitting into the typical reported optimal temperature range of $25-35^{\circ} \mathrm{C}$. (Robertson and Gijs Kuenen, 2006). Previous modelling of autotrophic thiocyanate degradation also suggested high temperature sensitivity (Kim et al. 2013b). It is therefore crucial that temperature is well controlled in treatment processes, such as activated sludge, to ensure effective degradation. This is particularly important in temperate climates, such as the UK, where the natural wastewater temperature is between $8-21^{\circ} \mathrm{C}$.

\subsection{Molecular microbial ecology}

Deoxyribonucleic acid sequencing analysis showed that the mixed culture was dominated by an uncultured species of Thiobacillus (26\%) (Figure 4). The 16S sequence linked to $\mathrm{SCN}^{-}$degradation in the mixed culture was previously identified by Bai et al. (2011), however, the sequence was not assigned to a species. The Thiobacillus genus was similarly the most abundant genus in a continuous flow bioreactor degrading $\mathrm{SCN}^{-}$reported by Kantor et al. (Kantor et al., 2015). Furthermore, the activated sludge biomass contained a notable abundance of the genera Mizugakiibacter (13\%), Comamonas (12\%) and Rhodanobacter (11\%) (Figure 4). Mizugakiibacter and Rhodanobacter are known for their iron-oxidising and nitrate reducing abilities (Wang et al., 2017) whilst Comamonas has been associated with a wide range of abilities including the degradation of phenol (Zámocký et al., 2001). Members of the 
Rhodanobacter and Comamonas genera were also observed in the bioreactors reported by Kantor et al. (Kantor et al., 2015).

The mixed culture was shown to effectively degrade $\mathrm{SCN}^{-}$over a range of initial concentrations (Table 2). The Thiobacillus genus has been recognised for $\mathrm{SCN}^{-}$ degradation for many years. Despite this, species within the Thiobacillus genus have been subjected to significant reclassification as from an original group of 17 species, only 3 species remain in the genera of Thiobacillus (T. aquaesulis, T. thioparus and T. denitrificans) (Kelly and Wood, 2000a). Of the Thiobacillus species, only T. thioparus and $T$. denitrificans have been documented to be capable of utilising thiocyanate as the sole source of energy (Kelly and Wood, 2000b) suggesting that the species present within the activated sludge were related to either T.thioparus or T. denitrificans. Whilst $T$. thioparus and $T$. denitrificans are genetically very similar (98\% similarity) (Kelly and Wood, 2000b), T. denitrificans is distinguished from all other Thiobacillus species due to its ability to grow as a facultative anaerobe (Kelly and Wood, 2000b). Thiobacillus thioparus on the other hand is capable of reducing nitrate but not nitrite. Nitrite accumulation has been observed in the pre-denitrification ASP (Raper et al., 2019) which could suggest a metabolic similarity to T.thioparus. Despite this, an ambiguous species of the genus Rhodanobacter was also identified in the mixed culture (Figure 4). As some species of this genus are capable of nitrate reduction but not nitrite reduction (Lee et al., 2007) nitrite accumulation may also be attributed to other species in the mixed culture. As the $\mathrm{SCN}^{-}$degradation investigation was focused on the properties of the mixed culture, it is therefore not possible to ascertain the full metabolic capability of $\mathrm{SCN}^{-}$degraders. Further work is required to characterise the Thiobacillus species using pure cultures. 


\section{Conclusions}

A mixed culture, taken from an aerobic ASP treating coke wastewater, was dominated by an uncultured species of Thiobacillus (26\%) and was capable of degrading $\mathrm{SCN}^{-}$at a range of concentrations (109-2109 $\mathrm{mg} / \mathrm{L})$. Thiocyanate was hypothesised to be hydrolysed/oxidised to $\mathrm{NH}_{4}{ }^{+}-\mathrm{N}$ and sulphate, but at $\mathrm{SCN}^{-}$concentrations $>110 \mathrm{mg} / \mathrm{L} \mathrm{a}$ rapid accumulation of $\mathrm{OCN}^{-}$was believed to reduce cyanase activity preventing the formation of $\mathrm{NH}_{4}{ }^{+}$. The uncultured Thiobacillus displayed similar metabolic capabilities to Thiobacillus denitrificans and Thiobacillus thioparus with optimal degradation occurring at mesophilic temperatures. Phenol, $\mathrm{NH}_{4}{ }^{+}-\mathrm{N}$ and $\mathrm{NH}_{2} \mathrm{OH}$ reduced $\mathrm{SCN}^{-}$ degradation efficiencies and should be controlled in the ASP influent to enable compliance with the IED emission limit of $>4 \mathrm{mg} / \mathrm{L}$.

\section{Acknowledgements}

This work was supported by Tata Steel UK and the Natural Environment Research Council [grant number NE/K007424/1]. 


\section{References}

Anderson, P.M., Little, R.M., 1986. Kinetic properties of Cyanase. Biochemistry 25, 1621-1626. doi:10.1016/0031-9422(89)80101-3

Bai, Y., Sun, Q., Sun, R., Wen, D., Tang, X., 2011. Bioaugmentation and Adsorption Treatment of Coking Wastewater Containing Pyridine and Quinoline Using Zeolite-Biological Aerated Filters. Environ. Sci. Technol. 45, 1940-1948.

Bai, Y., Sun, Q., Zhao, C., Wen, D., Tang, X., 2010. Bioaugmentation treatment for coking wastewater containing pyridine and quinoline in a sequencing batch reactor. Appl. Microbiol. Biotechnol. 87, 1943-1951. doi:10.1007/s00253-010-2670-8

Boucabeille, C., Bories, A., Ollivier, P., 1994. Degradation of thiocyanate by a bacterial coculture. Biotechnol. Lett. 16, 425-430.

Caporaso, J.G., Kuczynski, J, Stombaugh, J., Bittinger, K., Bushman, F.D., Costello, E.K., Fierer, N., Peña, A.G., Goodrich, J.K., Gordon, J.I., Huttley, G.A., Kelley, S.T., Knights, D., Koenig, J.E., Ley, R.E., Lozupone, C.A., McDonald, D., Muegge, B.D., Pirrung, M., Reeder, J., Sevinsky, J.R., Turnbaugh, P.J., Walters, W.A., Widmann, J., Yatsunenko, T., Zaneveld, J., Knight, R., 2010. QIIME allows analysis of high-throughput community sequencing data. Nat. Methods Corresp. 7, $335-336$.

Chaudhari, A.U., Kodam, K.M., 2010. Biodegradation of thiocyanate using co-culture of Klebsiella pneumoniae and Ralstonia sp . Environ. Biotechnol. 85, 1167-1174. doi:10.1007/s00253-009-2299-7

Combarros, R.G., Collado, S., Laca, A., Diaz, M., 2015. Conditions and Mechanisms in 
Thiocyanate Biodegradation. J. Residuals Sci. Technol. 12, 113-124. doi:10.12783/issn.1544-8053/12/3/1

Douglas Gould, W., King, M., Mohapatra, B.R., Cameron, R.A., Kapoor, A., Koren, D.W., 2012. A critical review on destruction of thiocyanate in mining effluents. Miner. Eng. 34, 38-47. doi:10.1016/j.mineng.2012.04.009

Eaton, A., 2005. Standard methods for the examination of water and wastewater, $21 \mathrm{st}$ ed. American Public Health Association.

European Commission, 2013. Best Available Techniques (BAT) Reference Document for Iron and Steel Production, Industrial Emissions Directive 2010/75/EU. doi:10.2791/97469

Gerardi, M.H., 2002. Nitrification and Denitrification in the Activated Sludge Process. John Wiley \& Sons, United States of America. doi:10.1002/0471216682

Grigor, N. V, Kondrat'eva, T.F., Krasil'nikova, E.N., Karavaiko, G.I., 2006. Mechanism of Cyanide and Thiocyanate Decomposition by an Association of Pseudomonas putida and Pseudomonas stutzeri Strains. Microbiology 75, 320-328. doi:10.1134/S0026261706030052

Grigor, N. V, Smirnova, Y. V, Dulov, L.E., 2009. Thiocyanate Decomposition under Aerobic and Oxygen-Free Conditions by the Aboriginal Bacterial Community Isolated from the Waste Water of a Metallurgical Works. Microbiol. Res. 78, 402406. doi:10.1134/S002626170904002X

Hamady, M., Knight, R., Stern, A., Mick, E., Tirosh, I., Hamady, M., Knight, R., 2012. Microbial community profiling for human microbiome projects : Tools, techniques, 
and challenges. Next-Generation DNA Seq. 1141-1152. doi:10.1101/gr.085464.108

Huang, H., Feng, C., Pan, X., Wu, H., Ren, Y., Wu, C., Wei, C., 2013. Thiocyanate Oxidation by Coculture from a Coke Wastewater Treatment Plant. J. Biomater. Nanobiotechnol. 4, 37-46. doi:10.4236/jbnb.2013.42A005

Hung, C.-H., Pavlostathis, S.G., 1997. Aerobic biodegradation of thiocyanate. Water Res. 31, 2761-2770. doi:10.1016/S0043-1354(97)00141-3

Hung, C., Pavlostathis, S.G., 1999. Kinetics and Modeling of Autotrophic Thiocyanate Biodegradation. Biotechnol. Bioeng. 62.

ISO, 1990. ISO 6439:1990: Water quality — Determination of phenol index — 4Aminoantipyrine spectrometric methods after distillation.

Jeong, Y.-S., Chung, J.S., 2006. Biodegradation of thiocyanate in biofilm reactor using fluidized-carriers. Process Biochem. 41, 701-707. doi:10.1016/j.procbio.2005.09.004

Kantor, R.S., van Zyl, A.W., van Hille, R.P., Thomas, B.C., Harrison, S.T.L., Banfield, J.F., 2015. Bioreactor microbial ecosystems for thiocyanate and cyanide degradation unravelled with genome-resolved metagenomics. Environ. Microbiol. 17, 4929-4941. doi:10.1111/1462-2920.12936

Katayama, Y., Naraharas, Y., Inoues, Y., Amanon, F., Kanagawall, T., Kuraishi, H., 1992. A Thiocyanate Hydrolase of Thiobacillus thioparus. J. Biol. Chem. 267, $9170-9175$. 
Kelly, D.P., Wood, A.P., 2000a. Reclassification of some species of Thiobacillus Acidithiobacillus gen . nov ., Halothiobacillus. Int. J. Syst. Evol. Microbiol. 50, $511-516$.

Kelly, D.P., Wood, A.P., 2000b. Confirmation of Thiobacillus denitrificans as a species of the genus Thiobacillus, in the $\beta$-subclass of the Proteobacteria, with strain NCIMB 9548 as the type strain. Int. J. Syst. Evol. Microbiol. 50, 547-550. doi:10.1099/00207713-50-2-547

Kim, J., Cho, K.J., Han, G., Lee, C., Hwang, S., 2013. Effects of temperature and pH on the biokinetic properties of thiocyanate biodegradation under autotrophic conditions. Water Res. 47, 251-258. doi:10.1016/j.watres.2012.10.003

Kim, S., Katayama, Y., 2000. Effect of growth conditions on thiocyanate degradation and emission of carbonyl sulfide by Thiobacillus Thioparus THI115. Water Res. $34,2887-2894$.

Kim, Y.M., Cho, H.U., Lee, D.S., Park, C., Park, D., Park, J.M., 2011. Response of nitrifying bacterial communities to the increased thiocyanate concentration in predenitrification process. Bioresour. Technol. 102, 913-922. doi:10.1016/j.biortech.2010.09.032

Kim, Y.M., Park, D., Jeon, C.O., Lee, D.S., Park, J.M., 2008. Effect of HRT on the biological pre-denitrification process for the simultaneous removal of toxic pollutants from cokes wastewater. Bioresour. Technol. 99, 8824-32. doi:10.1016/j.biortech.2008.04.050

Kim, Y.M., Park, H., Cho, K.H., Park, J.M., 2013. Long term assessment of factors affecting nitrifying bacteria communities and N-removal in a full-scale biological 
process treating high strength hazardous wastewater. Bioresour. Technol. 134, 180-189. doi:10.1016/j.biortech.2013.02.036

Kozliak, E.I., Fuchs, J. a, Guilloton, M.B., Anderson, P.M., Kozliak, E.I., Fuchs, J. a, Guilloton, M.B., 1995. Role of bicarbonate / CO2 in the inhibition of Escherichia coli growth by cyanate . Role of Bicarbonate / CO 2 in the Inhibition of Escherichia coli Growth by Cyanate 177, 3213-3219.

Lee, C., Kim, J., Chang, J., Hwang, S., 2003. Isolation and identification of thiocyanate utilizing chemolithotrophs from gold mine soils. Biodegradation 14, 183-188.

Lee, C., Kim, J., Do, H., Ã, S.H., 2008. Monitoring thiocyanate-degrading microbial community in relation to changes in process performance in mixed culture systems near washout 42, 1254-1262. doi:10.1016/j.watres.2007.09.017

Lee, C.S., Kim, K.K., Aslam, Z., Lee, S.T., 2007. Rhodanobacter thiooxydans sp. nov., isolated from a biofilm on sulfur particles used in an autotrophic denitrification process. Int. J. Syst. Evol. Microbiol. 57, 1775-1779. doi:10.1099/ijs.0.65086-0

Marañón, E., Vázquez, I., Rodríguez, J., Castrillón, L., Fernández, Y., López, H., 2008. Treatment of coke wastewater in a sequential batch reactor (SBR) at pilot plant scale. Bioresour. Technol. 99, 4192-8. doi:10.1016/j.biortech.2007.08.081

Pan, J., Ma, J., Wu, H., Ren, Y., Fu, B., He, M., Zhu, S., Wei, C., 2018a. Simultaneous removal of thiocyanate and nitrogen from wastewater by autotrophic denitritation process. Bioresour. Technol. 267, 30-37. doi:10.1016/j.biortech.2018.07.014

Pan, J., Wei, C., Fu, B., Ma, J., Preis, S., Wu, H., Zhu, S., 2018b. Simultaneous nitrite and ammonium production in an autotrophic partial denitrification and 
ammonification of wastewaters containing thiocyanate. Bioresour. Technol. 252, 20-27. doi:10.1016/j.biortech.2017.12.059

Paruchuri, Y.L., Shivaraman, N., Kumaran, P., 1990. Microbial transformation of thiocyanate. Environ. Pollut. 68, 15-28. doi:10.1016/0269-7491(90)90011-Z

Quast, C., Pruesse, E., Yilmaz, P., Gerken, J., Schweer, T., Yarza, P., Peplies, J., Glöckner, F.O., 2013. The SILVA ribosomal RNA gene database project: Improved data processing and web-based tools. Nucleic Acids Res. 41, 590-596. doi:10.1093/nar/gks1219

Quince, C., Lanzen, A., Davenport, R.J., Turnbaugh, P.J., 2011. Removing noise from pyrosequenced amplicons. BMC Bioinformatics 12, 38. doi:10.1186/1471-2105$12-38$

Raper, E., Fisher, R., Anderson, D.R., Stephenson, T., Soares, A., 2019. Nitrogen removal from coke making wastewater through a pre-denitrification activated sludge process. Sci. Total Environ. 666, 31-38.

Raper, E., Soares, A., Chen, J., Sutcliffe, A., Aries, E., Anderson, D.R., Stephenson, T., 2017. Enhancing the removal of hazardous pollutants from coke making wastewater by dosing activated carbon to a pilot-scale activated sludge process. J. Chem. Technol. Biotechnol. 92, 2325-2333. doi:10.1002/jctb.5231

Robertson, L.A., Gijs Kuenen, J., 2006. The Genus Thiobacillus, in: Dworkin, M., Falkow, S., Rosenberg, E., Schleifer, K.-H., Stackebrandt, E. (Eds.), The Prokaryotes. Springer-Verlag, New York.

Sorokin, D.Y., Tourova, T.P., Lysenko, A.M., Kuenen, J.G., 2001. Microbial 
Thiocyanate Utilization under Highly Alkaline Conditions. Appl. Environ. Microbiol. 67, 528-38. doi:10.1128/AEM.67.2.528

Sorokin, D.Y., Tourova, T.P., Antipov, A.N., Muyzer, G., Kuenen, J.G., 2004. Anaerobic growth of the haloalkaliphilic denitrifying sulfur-oxidizing bacterium Thialkalivibrio thiocyanodenitrificans sp . nov . with thiocyanate Printed in Great Britain. Microbiology 150, 2435-2442. doi:10.1099/mic.0.27015-0

Staib, C., Lant, P., 2007. Thiocyanate degradation during activated sludge treatment of coke-ovens wastewater. Biochem. Eng. J. 34, 122-130. doi:10.1016/j.bej.2006.11.029

The Institution of Gas Engineers, 1971. Recommended analytical methods for gas works and coke oven effluents: Booklet 3: Thiocyanate.

Vázquez, I., Rodríguez, J., Marañón, E., Castrillón, L., Fernández, Y., 2006. Simultaneous removal of phenol, ammonium and thiocyanate from coke wastewater by aerobic biodegradation. J. Hazard. Mater. 137, 1773-80. doi:10.1016/j.jhazmat.2006.05.018

Walsh, M.A., Otwinowski, Z., Perrakis, A., Anderson, P.M., Joachimiak, A., 2000. Structure of cyanase reveals that a novel dimeric and decameric arrangement of subunits is required for formation of the enzyme active site. Structure 8, 505-514. doi:10.1016/S0969-2126(00)00134-9

Wang, R., Yang, C., Zhang, M., Xu, S.-Y., Dai, C.-L., Liang, L.-Y., Zhao, H.-P., Zheng, P., 2017. Chemoautotrophic denitrification based on ferrous iron oxidation: Reactor performance and sludge characteristics. Chem. Eng. J. 313, 693-701. doi:10.1016/j.cej.2016.12.052 
Watts, M.P., Moreau, J.W., 2016. New insights into the genetic and metabolic diversity of thiocyanate-degrading microbial consortia. Appl. Microbiol. Biotechnol. 100, 1101-1108. doi:10.1007/s00253-015-7161-5

Zámocký, M., Godočíková, J., Koller, F., Polek, B., 2001. Potential application of catalase-peroxidase from Comamonas terrigena $\mathrm{N} 3 \mathrm{H}$ in the biodegradation of phenolic compounds. Antonie van Leeuwenhoek, Int. J. Gen. Mol. Microbiol. 79, 109-117. doi:10.1023/A:1010294130534 


\section{Figure 1}

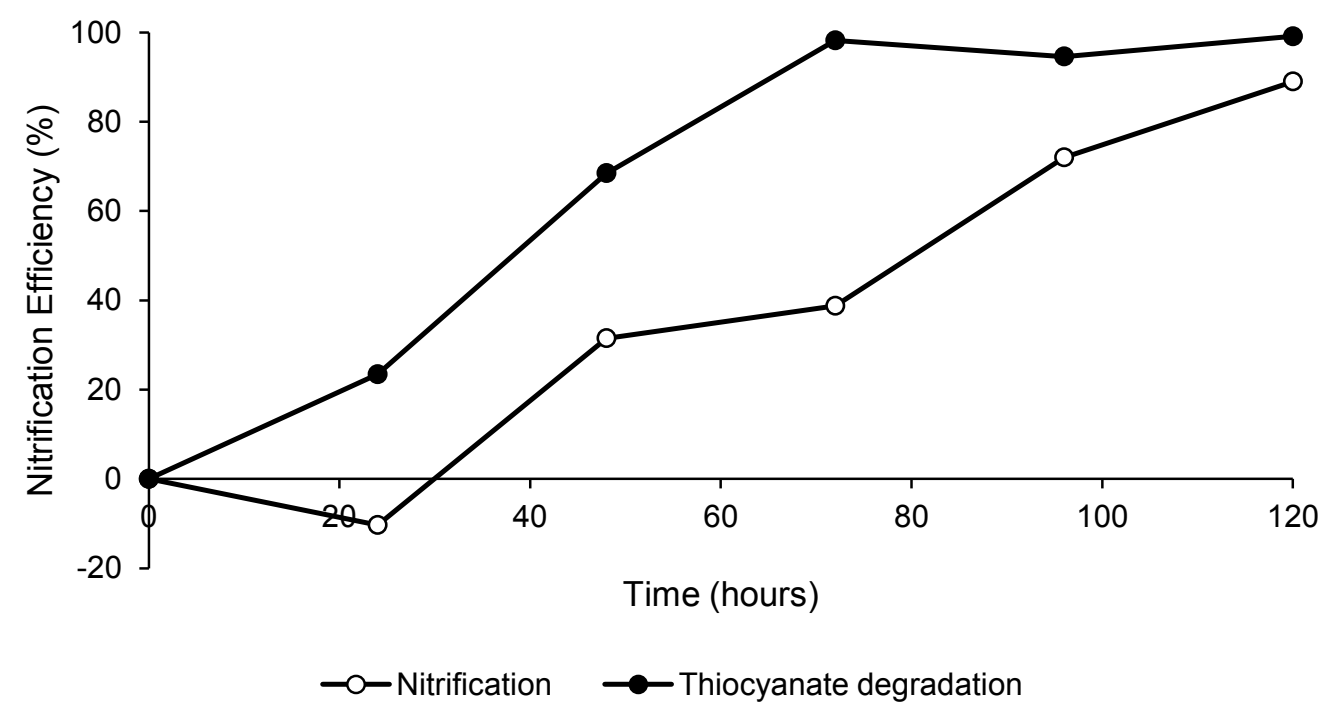

Fig. 1. Thiocyanate and nitrification treatment efficiency by the mixed culture during batch tests $\bullet-\mathrm{SCN}^{-}$removal efficiency $\circ$ - Nitrification efficiency. $\mathrm{SCN}^{-}$degradation proceeds faster than nitrification. 


\section{Figure 2:}
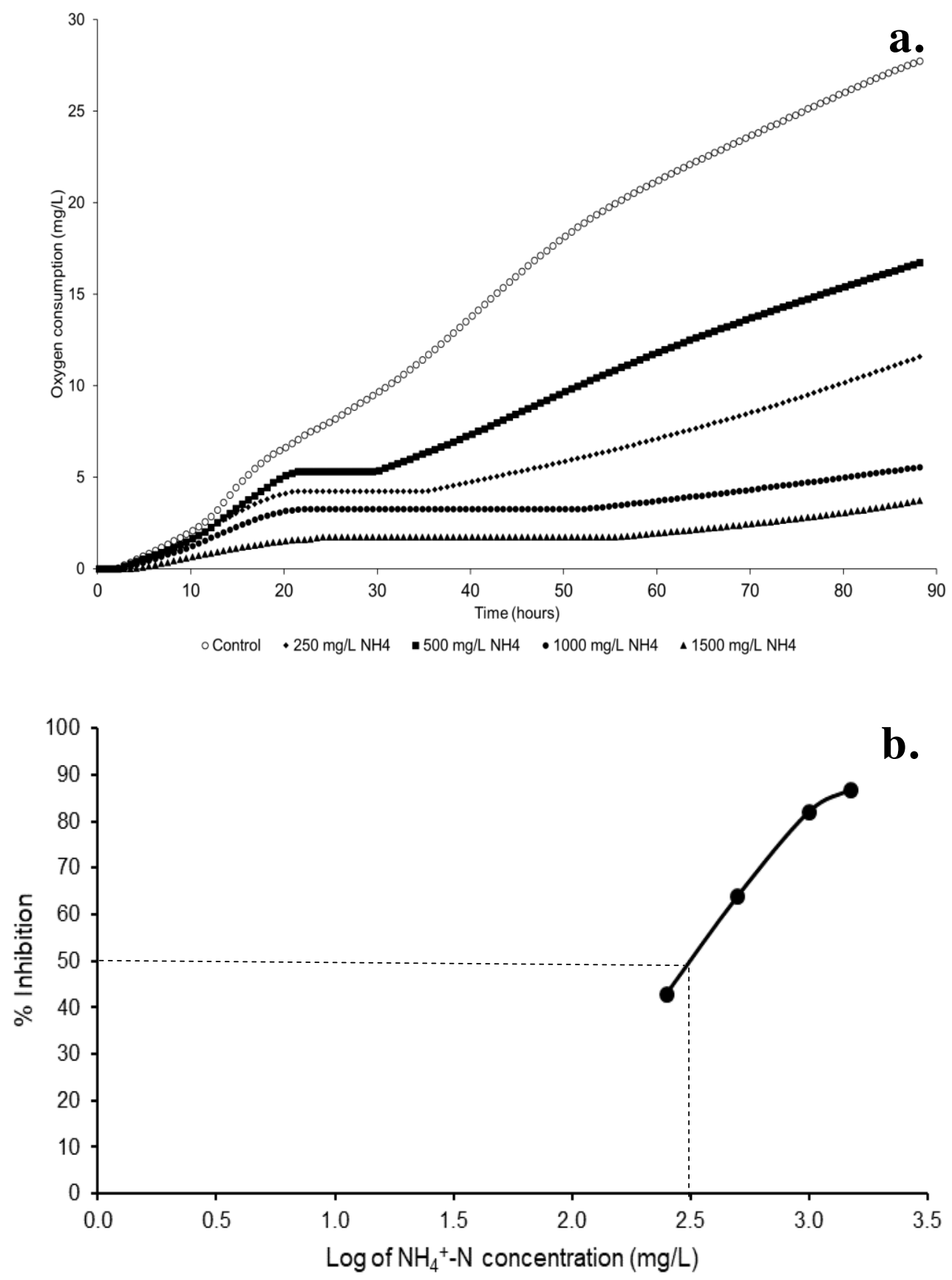

Fig. 2. Impact of $\mathrm{NH}_{4}{ }^{+}-\mathrm{N}$ addition on the mixed culture over a 4-day duration in the respirometer a. Reduced oxygen uptake as a result of increased $\mathrm{NH}_{4}{ }^{+}-\mathrm{N}$ concentrations b. A half maximal inhibitory concentration (IC50) of $312 \mathrm{mg} / \mathrm{L}_{\text {of }} \mathrm{NH}_{4}{ }^{+}-\mathrm{N}$ on $\mathrm{SCN}^{-}$removal. 


\section{Figure 3:}

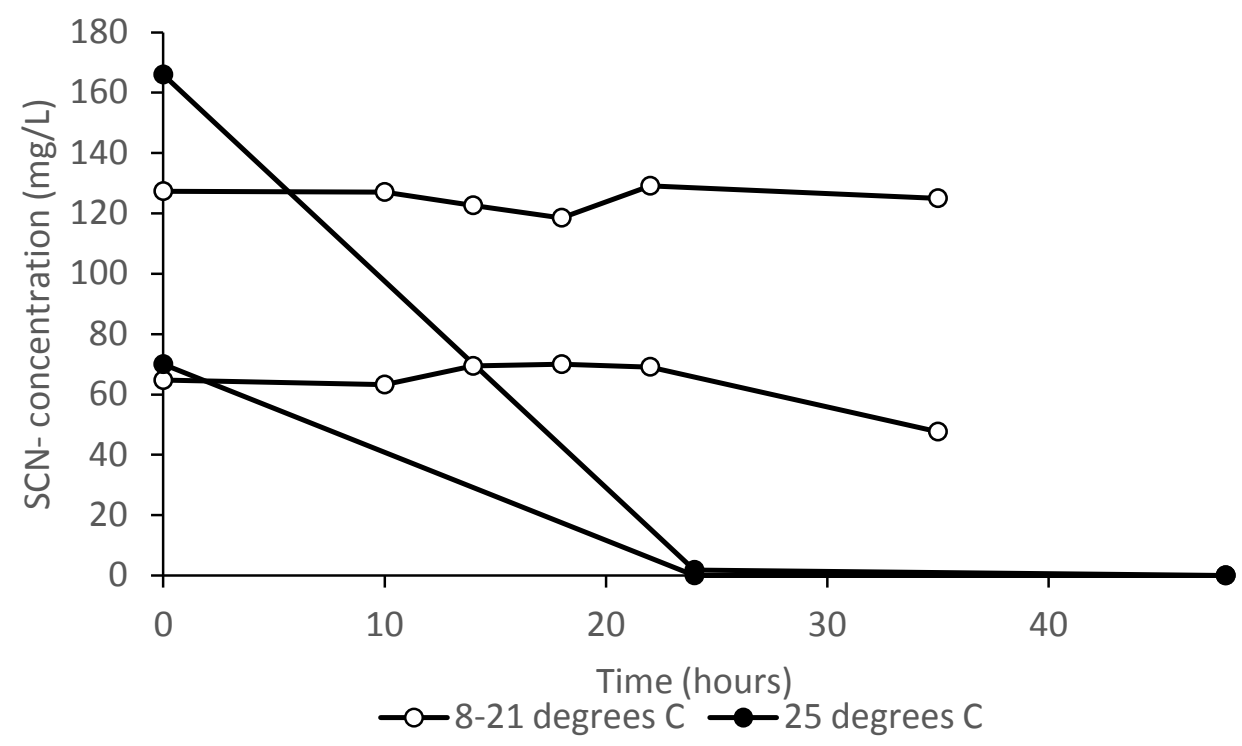

Fig. 3. Impact of temperature on $\mathrm{SCN}^{-}$degradation in mixed culture batch tests. Thiocyanate degradation decreases when temperatures are sub-mesophilic. 


\section{Figure 4:}

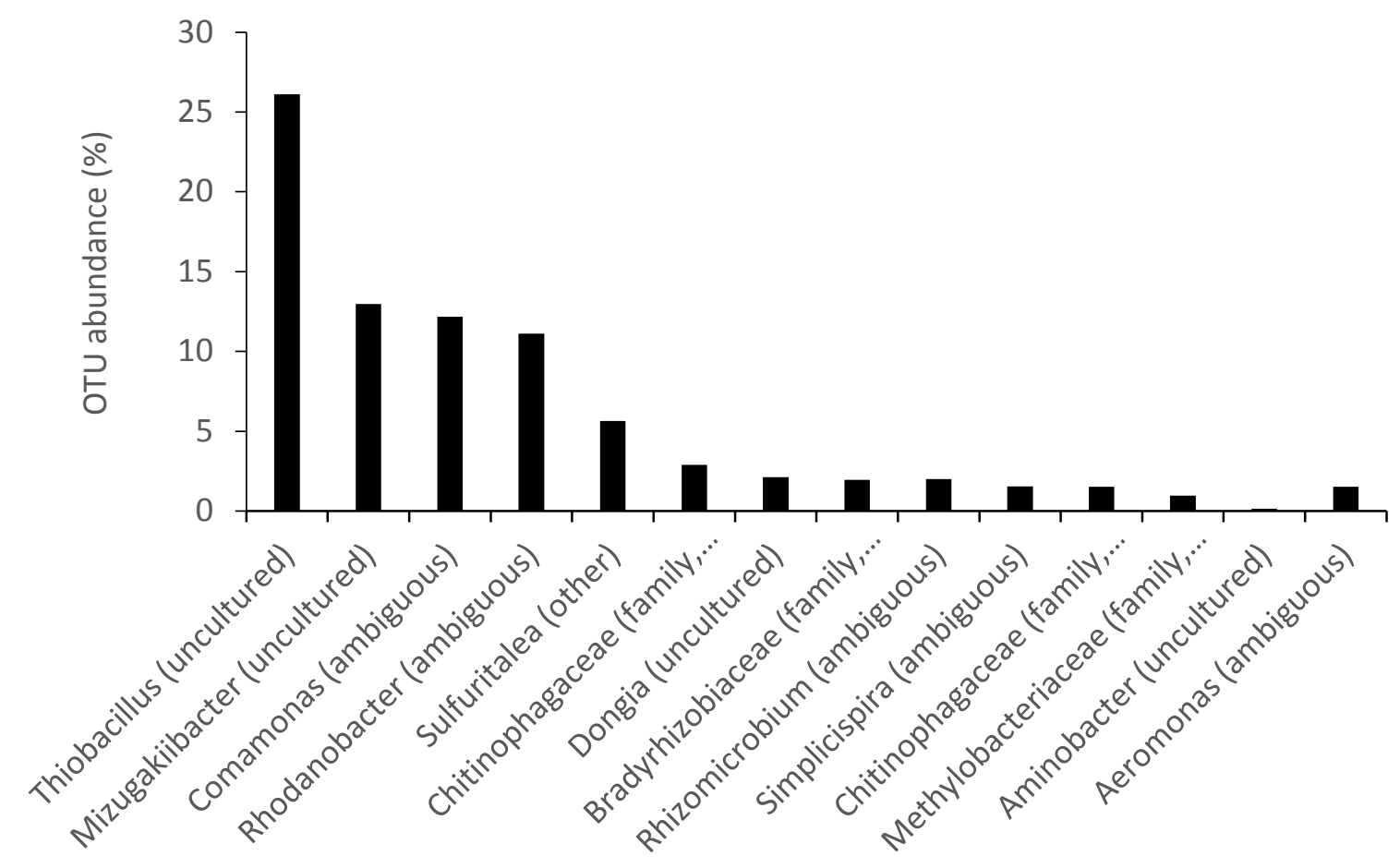

Fig. 4. Molecular microbial analysis displaying operational taxonomic units (OTUs) and relative abundance in the activated sludge mixed culture determined through PCR gene sequencing. An uncultured species of Thiobacillus was dominant in the mixed culture. 
Table 1

Thiocyanate degradation pathway.

\begin{tabular}{|c|c|c|c|c|}
\hline & Species & $\begin{array}{c}\text { Oxygen } \\
\text { availability }\end{array}$ & $\mathrm{SCN}^{-}$degradation pathway & Type of wastewater and reference \\
\hline \multirow{13}{*}{ 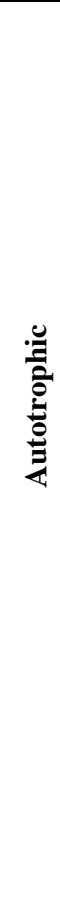 } & \multirow[t]{4}{*}{ Mixed culture } & \multirow[t]{4}{*}{ Aerobic } & $\mathrm{SCN}^{-}+\mathrm{H}_{2} \mathrm{O} \rightarrow \mathrm{HCNO}+\mathrm{HS}^{-}$ & Photo-processing (Hung and Pavlostathis, 1997) \\
\hline & & & $\begin{array}{l}\mathrm{HCNO}+\mathrm{H}_{2} \mathrm{O} \rightarrow \mathrm{NH}_{4}^{+}+\mathrm{HCO}_{3}^{-} \\
\mathrm{HS}^{-}+2 \mathrm{O}_{2} \rightarrow \mathrm{SO}_{4}^{2-}+\mathrm{H}^{+}\end{array}$ & $\begin{array}{l}\text { Synthetic photo-processing (Hung and Pavlostathis, } \\
\text { 1999) }\end{array}$ \\
\hline & & & 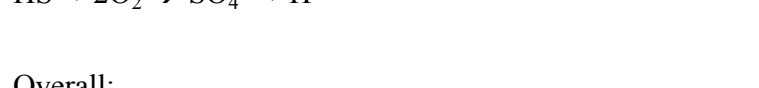 & $\begin{array}{l}\text { * Metallurgical (synthetic and reused water) (Grigor et } \\
\text { al., 2009) }\end{array}$ \\
\hline & & & $\mathrm{SCN}^{-}+2 \mathrm{O}_{2}+3 \mathrm{H}_{2} \mathrm{O} \rightarrow \mathrm{NH}_{4}^{+}+\mathrm{HCO}_{3}^{-}+\mathrm{SO}_{4}{ }^{2-}+\mathrm{H}^{+}$ & $\begin{array}{l}\text { Synthetic Burkholderia sp., Chryseobacterium sp., } \\
\text { Ralstonia sp.(Huang et al., 2013) }\end{array}$ \\
\hline & \multirow{3}{*}{$\begin{array}{l}\text { Mixed culture: dominated by Pseudomonas and } \\
\text { Bacillus }\end{array}$} & \multirow[t]{3}{*}{ Aerobic } & $\mathrm{SCN}^{-}+2 \mathrm{H}_{2} \mathrm{O}+2 \mathrm{O}_{2} \rightarrow \mathrm{CO}_{2}+\mathrm{SO}_{4}^{2-}+\mathrm{NH}_{4}^{+}$ & \multirow[t]{3}{*}{ Coke wastewater (Paruchuri et al., 1990) } \\
\hline & & & $\mathrm{SCN}^{-}+2 \mathrm{H}_{2} \mathrm{O} \rightarrow \mathrm{CO}_{2}+\mathrm{S}^{2-}+\mathrm{NH}_{4}^{+}$ & \\
\hline & & & $\mathrm{SCN}^{-}+3 \mathrm{H}_{2} \mathrm{O}+0.5 \mathrm{O}_{2} \rightarrow \mathrm{CO}_{2}+\mathrm{S}^{\mathrm{o}}+\mathrm{NH}_{4}^{+}+2 \mathrm{OH}^{-}$ & \\
\hline & \multirow{2}{*}{$\begin{array}{l}\text { Mixed Culture } \\
\text { Thiobacillus thioparus }\end{array}$} & Aerobic & $\mathrm{SCN}^{-}+2 \mathrm{H}_{2} \mathrm{O}+2 \mathrm{O}_{2} \rightarrow \mathrm{CO}_{2}+\mathrm{SO}_{4}{ }^{2-}+\mathrm{NH}_{4}^{+}$ & Coke wastewater (Staib and Lant, 2007) \\
\hline & & Aerobic & $\mathrm{SCN}^{-}+2 \mathrm{H}_{2} \mathrm{O} \rightarrow \mathrm{COS}+\mathrm{NH}_{3}+\mathrm{OH}^{-}$ & Synthetic (Katayama et al., 1992) \\
\hline & $\begin{array}{l}\text { Acinetobacter johnsonii and Pseudomonas } \\
\text { diminuta }\end{array}$ & Aerobic & $\mathrm{SCN}^{-} \rightarrow \mathrm{S}_{2} \mathrm{O}_{3}^{2-} \rightarrow \mathrm{SO}_{4}^{2-}$ & Synthetic (Boucabeille et al., 1994) \\
\hline & Thialkalivibrio & Aerobic/ & \multirow{2}{*}{$\begin{array}{l}5 \mathrm{SCN}^{-}+\mathrm{NO}_{3}^{-}+\mathrm{H}_{2} \mathrm{O}+8 \mathrm{H}^{+}+5 \mathrm{HCO}_{3}^{-} \rightarrow 5 \mathrm{SO}_{4}^{2-}+5 \mathrm{NH}_{3}+ \\
10 \mathrm{CO}_{2}+4 \mathrm{~N}_{2}\end{array}$} & \multirow[t]{2}{*}{ Soda lake sediment (Sorokin et al., 2004) } \\
\hline & thiocyano denitrificans & Anaerobic & & \\
\hline & Thiobacillus denitrificans & Anoxic & $\begin{array}{l}5 \mathrm{SCN}^{-}+\mathrm{NO}_{3}^{-}+\mathrm{H}_{2} \mathrm{O}+8 \mathrm{H}^{+}+5 \mathrm{HCO}_{3}^{-} \rightarrow 5 \mathrm{SO}_{4}^{2-}+5 \mathrm{NH}_{3}+ \\
10 \mathrm{CO}_{2}+4 \mathrm{~N}_{2}\end{array}$ & (Robertson and Gijs Kuenen, 2006)* \\
\hline \multirow{4}{*}{ 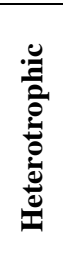 } & \multirow{2}{*}{$\begin{array}{l}\text { Pseudomonas putida (strain 21) and } \\
\text { Pseudomonas stutzeri (strain 18) }\end{array}$} & \multirow[t]{2}{*}{ Aerobic } & $\mathrm{SCN}^{-}+\mathrm{H}_{2} \mathrm{O} \rightarrow \mathrm{NH}_{3}+\mathrm{CO}_{2}+\mathrm{S}_{2} \mathrm{O}_{3}^{2-}$ & \multirow[t]{2}{*}{ Synthetic (Grigor et al., 2006) } \\
\hline & & & $\begin{array}{l}\text { Further converted by } \mathrm{P} \text {. putilda strain } 21 \text { to: } \\
\mathrm{S}_{2} \mathrm{O}_{3}{ }^{2-} \rightarrow \mathrm{S}_{4} \mathrm{O}_{6}{ }^{2-} \rightarrow \mathrm{S}_{3} \mathrm{O}_{6}{ }^{2-}\end{array}$ & \\
\hline & Soil isolate $26 \mathrm{~B}$ & Aerobic & $\mathrm{SCN}^{-}+\mathrm{H}_{2} \mathrm{O} \rightarrow \mathrm{NH}_{3}+\mathrm{CO}_{2}+\mathrm{S}_{2} \mathrm{O}_{3}^{2-}$ & Synthetic (Stratford et al., 1994)* \\
\hline & Klebsiella pneumoniae and Ralstonia sp. & Aerobic & $\mathrm{SCN}^{-}+2 \mathrm{H}_{2} \mathrm{O} \rightarrow \mathrm{COS}+\mathrm{NH}_{3}+\mathrm{OH}^{-}$ & Synthetic (Chaudhari and Kodam, 2010) \\
\hline
\end{tabular}

* Inferred from text 


\section{Table 2}

Impact of initial $\mathrm{SCN}^{-}$concentration on $\mathrm{SCN}^{-}$removal and end product formation in the mixed culture after 5 days in the respirometer.

\begin{tabular}{|c|c|c|c|c|c|c|c|c|c|}
\hline \multirow[b]{2}{*}{$\mathrm{SCN}^{-}$} & \multicolumn{3}{|c|}{ Start $(\mathrm{mg} / \mathrm{L})$} & \multicolumn{6}{|c|}{ End $(\mathrm{mg} / \mathrm{L})$} \\
\hline & $\mathrm{NH}_{4}{ }^{+}-\mathrm{N}$ & $\mathrm{NO}_{3}{ }^{-}-\mathrm{N}$ & $\mathrm{NO}_{2}^{-}-\mathrm{N}$ & $\mathrm{SCN}^{-}$ & $\mathrm{NH}_{4}{ }^{+}-\mathrm{N}$ & $\mathrm{NO}_{3}{ }^{-}-\mathrm{N}$ & $\mathrm{NO}_{2}{ }^{-}-\mathrm{N}$ & $\begin{array}{c}\text { Theoretical } \mathrm{NH}_{4}{ }^{+}-\mathrm{N} \\
\text { concentration } *\end{array}$ & $\begin{array}{l}\text { Difference between } \\
\text { theoretical and } \\
\text { empirical } \mathrm{NH}_{4}^{+}-\mathrm{N}^{\dagger}\end{array}$ \\
\hline 109 & 72 & 5 & 2 & 1 & 106 & 3.4 & 37 & 100 & 6 \\
\hline 359 & $"$ & $"$ & $"$ & 291 & 101 & 7.2 & 14 & 165 & -64 \\
\hline 609 & $"$ & $"$ & $"$ & 527 & 98 & 10.6 & 17 & 230 & -132 \\
\hline 1109 & $"$ & $"$ & $"$ & 839 & 15.4 & 18.2 & 21 & 360 & -345 \\
\hline 2109 & $"$ & $"$ & $"$ & 890 & 4 & 25.4 & 17 & 620 & -616 \\
\hline
\end{tabular}

* Empirical data of $\mathrm{SCN}^{-}$degradation by the studied mixed culture demonstrates that one mole of $\mathrm{SCN}^{-}$forms 0.26 moles of $\mathrm{NH}_{4}{ }^{+}{ }^{-} \mathrm{N}$. Theoretical $\mathrm{NH}_{4}{ }^{+} \mathrm{N}$ concentration calculation: Start $\mathrm{NH}_{4}{ }^{+}-\mathrm{N}(\mathrm{mg} / \mathrm{L})+\left(0.26 \times \mathrm{Start} \mathrm{SCN}^{-}(\mathrm{mg} / \mathrm{L})\right.$.

$\dagger$ Difference between $\mathrm{NH}_{4}{ }^{+}-\mathrm{N}$ formation based on molar ratio of $\mathrm{SCN}^{-}$to $\mathrm{NH}_{4}{ }^{+}$and empirical $\mathrm{NH}_{4}{ }^{+}-\mathrm{N}$ concentration $=\mathrm{End} \mathrm{NH}_{4}{ }^{+}-\mathrm{N}(\mathrm{mg} / \mathrm{L})-\left(\mathrm{Start} \mathrm{NH}{ }_{4}^{+}-\mathrm{N}(\mathrm{mg} / \mathrm{L})+\right.$ $\left.\left(0.26 \times \operatorname{Start~SCN}^{-}(\mathrm{mg} / \mathrm{L})\right)\right)$ 